\title{
Framgång på tur. Kapital och sociala strategier i migranters berättelser om framgångsrika karriärer
}

\section{Erik Olsson}

SAMMANDRAG: Erik Olssons artikel baseras på intervjuer med 32 framgångsrika personer inom affärsvärlden och högskolan som alla invandrat till Sverige från Mellanöstern. Deras berättelser handlar om framgång trots att ursprunget gett dem sämre utgångslägen. De berättar om en uppväxt i samhällen med stor respekt för utbildning och om vikten av att ha ett bra kontaktnät. Detta kapital hade emellertid liten betydelse efter migrationen och en framgångsrik strategi var i stället att pragmatiskt mobilisera nytt kapital i form av ny utbildning, nya nätverk, hårt arbete och kunskap om spelets regler inom respektive profession. Eftersom framgångsrika karriärer på detta sätt ensidigt betingas av villkoren i det nya samhället, blir framgång för migranter beroende av att individerna anlägger en pragmatisk inställning till skillnader mellan samhällen. Detta innebär bland annat att migranter ofta får bortse från olika slags orättvisor och diskriminering.

NYCKELORD: migration; karriärer; framgångsrika migranter; berättelser; symboliskt kapital.

PUBLICERINGSHISTORIK: Originalpublicering.

ERIK OLSSON är professor i internationell migration och etniska relationer vid Stockholms universitet.

E-POSTADRESS: erik.olsson@socant.su.se

FÖRSLAG PÅ KÄLLANGIVELSE:

Olsson, Erik (2020) "Framgång på tur. Kapital och sociala strategier i migranters berättelser om framgångsrika karriärer”, i Arkiv. Tidskrift för sambällsanalys, nr I2, s. I4I-I74. DOI: https://doi.org/IO.I3068/2000-62I7.I2.4

(C) Erik Olsson/Arkiv förlag \& tidskrift 2020 (publicerad ıo december 2020)

Artikeln distribueras enligt en upphovsrättslicens från Creative Commons:

Erkännande-Ickekommersiell-IngaBearbetningar 3.0 Unported, som medger fri ickekommersiell användning och spridning i oförändrat skick så länge källan anges. 
Arkiv. Tidskrift för samhällsanalys är en sakkunniggranskad vetenskaplig tidskrift för samhällsvetenskap och historia. Samtliga artiklar publiceras fritt tillgängliga på:

$$
\text { www.tidskriftenarkiv.se }
$$

Beständig länk, DOI: https://doi.org/IO.I3068/2000-62I7

Den här artikeln finns tillgänglig i följande format:

PDF: via beständig länk, DOI: https://doi.org/IO.I3068/2000-62I7.I2.4

TRYCK: ingår i bokutgåva av numret, ISBN: 978 9I 79243388

Grafisk utformning och sidnumrering är identisk i pdf och tryck.

Samtliga artiklar i nr I2 (2020) nås via beständig länk, DOI: https://doi.org/IO.I3068/2000-62I7.I2

Arkiv. Tidskrift för sambällsanalys

ISSN: 2000-6217 (för elektronisk resurs)

ISSN: 2000-6225 (för tryckta nummer)

ges ut av

Stiftelsen Arkiv för främjande och spridning av samhällsvetenskaplig och historisk forskning

genom

Arkiv förlag \& tidskrift

Box 1559

SE-22I OI Lund

BESÖK: L Gråbrödersg 3 c, ipg

TEL: 046-I3 3920

ARKIV FÖRLAG: arkiv@arkiv.nu·www.arkiv.nu

TIDSKRIFTEN ARKIV: red@tidskriftenarkiv.se.www.tidskriftenarkiv.se

ANSVARIg UTGIVARE \& CHEFREDAKTÖR: Sven Hort

Administrativ Redaktör: David Lindberg

RedAKTörer: Per Dannefjord, Lisa Kings, Zhanna Kravchenko, Anna-Maria Sarstrand Marekovic 


\title{
Framgång på tur. Kapital och sociala strategier i migranters berättelser om framgångsrika karriärer
}

\author{
ERIK OLSSON
}

\section{Inledning}

Sverige har varit ett "invandringsland" i snart nittio år, men fortfarande är det relativt ovanligt att migranter tillhör det svenska samhällets övre skikt av höginkomsttagare och makthavare. Infödda svenskar har betydligt större chans att få ett kvalificerat yrke än vad invandrade har, och högutbildade infödda har dessutom markant högre inkomster än vad högutbildade med invandrad bakgrund har (Irastorza \& Bevelander 20I8). Flyktingar och andra invandrade från icke-västerländska länder är med några få undantag underrepresenterade inom de mer kvalificerade och välbetalda yrkesområdena. Det är mot den bakgrunden okontroversiellt att påstå att det svenska samhällets mest eftertraktade positioner i huvudsak är vikta för infödda svenskar. Det kan ha många orsaker - inte minst diskriminering (Behtoui 2006; Carlsson \& Roth 2007) - men

\footnotetext{
Artikeln är skriven inom projektet "Pathways to Success: the upcoming elite among descendants of migrants in Sweden". Projektet finansierades 20I4-I9 av Wallenbergstiftelsen, Marianne och Marcus Wallenbergs fond, och forskningen har bedrivits vid Socialantropologiska institutionen vid Stockholms universitet. Förutom projektledaren (artikelförfattaren) har Alireza Behtoui och Hege H Leivestad varit aktiva forskare inom projektet och genomfört de intervjuer som artikeln bygger på. Projektet har genererat ett antal publikationer, se till exempel Behtoui 2017, 2018; Behtoui \& Leivestad 20I8; Leivestad \& Olsson 2020; Olsson 2020; Olsson m.fl. 2018.
} 
hänger med stor sannolikhet samman med att såväl studiemeriter som yrkeserfarenheter från utomeuropeiska länder är mindre värda när de prövas i det svenska samhället.

Det finns dock ljusglimtar och undantag. De invandrade i Sverige har en relativt hög utbildningsnivå och deras barn som föds i Sverige utgör en allt större andel av landets högskoleutbildade (SCB 20I7). Såvida samhället kan hålla diskrimineringen i schack kan man ana att skillnaderna i inkomst och makt på längre sikt kommer att utjämnas (jfr Irastorza \& Bevelander 20I8). Frågor som rör diskriminering och validering av meriter får mer uppmärksamhet, och det finns en hel del tecken på att migranterna tar plats inom vissa av samhällets mer kvalificerade yrkesområden (jfr Frykman \& Öhlander 20I8).

Den här artikeln handlar om undantagsfallen. Vi möter individer som i unga år flyttade från ett land i Mellanöstern till Sverige och har gjort en framgångsrik karriär inom affärs- eller högskolevärlden. Artikeln baserar sig på intervjuer med 32 framgångsrika personer med bakgrund i Mellanöstern. Intervjuerna ser jag som berättelser om karriären och framgången i Sverige. Det är på olika sätt berättelser om utmaningar och strategier för att överkomma dessa som artikeln förmedlar.

Det går naturligtvis att ha olika syn på vad ordet "framgångsrik" betyder när det gäller yrkesrelaterade karriärer. Men det finns allmänt vedertagna uppfattningar om vad det innebär att ha framgång i sitt yrkesliv, som att ha uppnått hög status eller tjänat mycket pengar. Jag stipulerar ingen precis definition av ordet. Jag konstaterar bara att intervjupersonerna i någon mening har lyckats nå långt i sina karriärer jämfört med många andra i samhället, och att de har tagit sig över många hinder på vägen. Mitt huvudintresse rör inte prestationen i sig utan vad individerna lyfter fram som betydelsefullt för att de skulle nå så långt som de har gjort.

Den här studien gör självfallet inga anspråk på att representera migranter i allmänhet. Det är i någon mening vinnarna jag lyfter fram. Förmodligen har "genomsnittsinvandrare" svårt att känna igen sig i deras berättelser. Analysen av dessa vinnares berättelser har varit ett sätt att lyfta på locket till de strategier som använts av individer som förefaller ha haft exceptionell framgång i sin karriär trots ogynnsamma utsikter. 
De intervjuade har återgett de beståndsdelar av sina biografier som de själva velat förmedla. Det rör sig således om ett subjektivt och reflektivt meningsskapande. Källan till detta meningsskapande är ganska fragmentariska individuella historier ur biografier som börjar någonstans $\mathrm{i}$ Mellanöstern.

En viktig bakgrund till den analys som jag gör i artikeln finns i Pierre Bourdieu och teorin om habitus och kapital (Bourdieu 1977, 1986, 1990). I min tolkning av Bourdieu kan individers karriärer ses som resultat av mobiliseringen av symboliskt kapital i form av till exempel utbildning (kulturellt kapital) eller sociala kontakter (socialt kapital). Att lyckas mobilisera sådana kapitalformer kan ge en katalysatoreffekt till det vi bär med oss i form av personlighetsdrag, läggning och social position och tillhörighet (till exempel klass, kön och ålder). Att äga ett symboliskt kapital är emellertid inte tillräckligt, utan ett kapital måste ha ett värde på en marknad där det kan omsättas. I karriärsammanhang kan en sådan marknad motsvara det som Bourdieu kallar ett socialt fält och vars grundläggande struktur kan beskrivas som ett nät av olika slags relationer där människor konkurrerar om något som de har gemensamt (Broady 1998:3). I Bourdieus perspektiv finns inga fasta växlingskurser. En viss uppsättning utbildningsmeriter och referenser kan vara värdefulla när en individ söker en kvalificerad anställning i ett visst sammanhang, men på en annan marknad, till exempel i ett annat land, har resurserna inte samma värde.

Det övergripande syftet med denna artikel är att ge insikter i karriärstrategier för framgångsrika migranter med ursprung i Mellanöstern. Med "strategier" avser jag handlingar och val som människor gör för att bevaka sina intressen och flytta fram sina positioner, i detta fall inom yrkeslivet. Eftersom många av intervjupersonerna redan hade inlett sin karriär i sina ursprungsländer var det viktigt att studera betydelsen av de individuella och sociala villkoren och förutsättningarna från deras uppväxt. Ett delsyfte är alltså att förstå den sociala bakgrundens betydelse för karriärstrategier i samband med migration.

Vi bör hålla i minnet att invandrade från framför allt icke-europeiska länder ofta utsätts för kränkande behandling och orättvisor i västerländska samhällen. Som regel är invandrade från Mellanöstern särskilt utsatta 
för diskriminering. Genom att analysera intervjupersonernas berättelser kommer jag i artikeln att undersöka hur symboliskt kapital mobiliseras i samband med migration och de sociala strategier som krävs för detta. Det handlar om deras personliga biografi från födelselandet till det liv de skaffat sig i Sverige och om hur de med den bakgrunden upplevt de utmaningar som följer med att göra en karriär i Sverige. De två yrkesområden som förekommer i artikeln är affärsvärlden och högskolevärlden, och mitt grundantagande är att dessa personer agerar inom olika sociala fält och att det kapital (meriter och kompetenser) de behöver mobilisera och de strategier som hjälper dem framåt därför skiljer sig åt.

I nästa avsnitt sätter jag in denna studie i ett forskningssammanhang med andra studier om framgångsrika migranter i Sverige. Därefter skissar jag en teoretisk utgångspunkt som framför allt hämtar inspiration från Bourdieus kapitalteori. De teoretiska utgångspunkterna följs av ett avsnitt där jag redovisar några av de metodologiska övervägandena bakom studien. I detta avsnitt beskriver jag också mer ingående intervjumaterialet och hur intervjuerna gick till. Därefter följer en beskrivning av den migration som dessa migranter ingår i och hur deras position kan se ut jämfört med andra migranters.

Den empiriska framställningen inleds med informanternas berättelser. Jag analyserar biografin över uppväxten i förhållande till den karriär de sedan gjort. Efter denna analys fortsätter jag med berättelserna om hur informanterna upplevt mötet med det svenska samhället och hur de förmått bära med sig det sociala och kulturella kapital som de byggt upp under sin uppväxt. Vad har detta kapital för betydelse när de ska göra karriär i Sverige, beroende på om de verkar inom affärsvärlden eller inom högskolan?

Avslutningsvis sammanfattar jag studiens resultat genom att sätta berättelserna i relation till mobiliseringen av kapital och migrationskontexten. 


\section{Framgångsrika migranter i Sverige}

Studien har inte så mycket forskning om framgångsrika grupper eller kategorier av migranter i Sverige att bygga vidare på. Det finns visserligen ett antal undersökningar om särskilda nationella kategorier som rent allmänt har klarat sig bättre än andra i det svenska samhället, exempelvis de östeuropeiska flyktingarna från 1960- och 1970-talet (Ekberg 1992), bosnierna från 1990-talet (Bennich-Björkman \& Likic-Brboric 2018; Ekberg 2016) och iranierna från 1980- och 1990-talet (Graham \& Khosravi 1997; Hosseini-Khaladjahi 1997; Kelly 2013). Men dessa studier ger ingen djupare kunskap om karriärvägar och strategier för de migranter som blivit framgångsrika (Sandelind \& Ådahl 20Io). Den främsta förklaringen är att en sammanslagning av mycket skilda vägar in i Sverige inom en nationell kategori sällan kan ge kunskap som går utöver det enskilda fallet. Exempelvis kan en närmare granskning av kategorin iranska migranter visa att det är relativt många av dem som utbildar sig och gör en professionell karriär i Sverige, men samtidigt är det många som hamnar i arbetslöshet och lågbetalda yrken. Det kan likväl i vissa sammanhang vara befogat att undersöka arbetsmarknadsstrategier för invandrade i termer av nationalitet och etnicitet. Det finns bland annat en ganska riklig litteratur om invandrade företagare där etnicitet är relevant (se översikt av Klinthäll m.fl. 20ı6; Najib 1999; Slavnic 20ı0). Å andra sidan ligger tyngdpunkten i denna litteratur mestadels på småskaliga företag, och den ger därför inte kunskap om just karriärvägar och strategier för framgångsrika individer.

Den litteratur som ligger närmast till hands är forskningen om högutbildade och professionella (till exempel Frykman \& Öhlander 20I8; Irastorza \& Bevelander 20I7, 20I8). Ett antal studier har behandlat de erfarenheter som invandrade akademiker har av den svenska arbetsmarknaden (Behtoui 20I7; Behtoui \& Leivestad 20I8; Mählck 20I3; Olsson m.fl. 20I8; Wolanik Boström 2005). En specifik yrkeskategori som har studerats är invandrade läkare (Frykman \& Mozetič 2020; Wolanik Boström \& Öhlander 20II, 20I2, 20I5; Öhlander m.fl. 2020).

En slutsats som går att dra av forskningen om högutbildade och professionella är att migranter i allmänhet får sämre utdelning på investerat 
kapital i utbildning än vad infödda svenskar får (Behtoui 2006; Behtoui \& Olsson 20I4; Katz \& Österberg 20I3). Utbildning lönar sig inte lika väl för de invandrade, och det finns självfallet anledning att ta till ordet "diskriminering" för att belysa sådana förhållanden. Ofta används termen de-skilling (se till exempel McNeil-Walsh 2008; Nowicka 20I2) för att beteckna den process som graderar ner migranters kompetens och ger migranterna en nackdel i konkurrensen om högre befattningar.

Migranter som siktar på att göra en karriär som leder till toppskiktet inom deras yrkesfält har rimligtvis större utmaningar framför sig än de flesta infödda. För att övervinna de-skilling och orättvisa system utvecklar de en repertoar av strategier, tänker jag mig. I anslutning till det kan en kvalitativ studie av välutbildade bosniska flyktingar vara upplysande (Bennich-Björkman \& Likic-Brboric 20I8). Den visade exempelvis att de hade en strategi där de medvetet agerade på ett sätt som de trodde skulle gagna deras integration. Flyktingarna kämpade för att bli erkända för sin kompetens och för att deras meriter skulle accepteras i det nya landet.

Det går inte att komma ifrån att migranter kan uppleva svårigheter att få sin kompetens erkänd och att vinna omgivningens respekt i det nya samhället. Exempelvis har de iranska migranterna ett rykte om sig att vara välintegrerade i det svenska samhället, och de har generellt sett en hög utbildningsnivå (jämfört med till exempel infödda svenskar se SCB 2017). Men trots det har många övergett den yrkeskarriär de påbörjat och kastat sig in i en ganska osäker tillvaro som småföretagare (Khosravi 1999). Melissa Kellys studie (2013) bekräftade att många av de högutbildade iranierna i Sverige kände sig besvikna på det svenska samhället och hade beslutat sig för att flytta till ett annat land eller återvända till Iran. Samtidigt tycktes det som om många red ut stormarna och försökte hantera sin situation som migranter genom att "betona sina likheter med svenskar och sin förmåga att enkelt passa in i det svenska samhället” (Kelly 20I3: I73). Detta är i linje med Ali Konyalis studier (20I4, 20I7) av svenskar med turkisk bakgrund som lyckats bra i sin karriär genom att ligga lågt och i första hand sköta sig själva på arbetsplatsen. I de studier av polska läkare som flyttat till Sverige som Wolanik Boström och Öhlander (20II, 20I2, 20I5) genomfört framgick hur det symbo- 
liska kapital som läkarna hade med sig från sitt polska arbetsliv kom att omförhandlas i det nya sammanhanget. Koder och normer som de tagit för givna, till exempel sådana som reglerar umgänget på arbetsplatsen, kanske inte längre gällde när de bytte jobb, och framför allt inte när de migrerade. Läkarna hanterade dessa normkonflikter bland annat genom att finjustera det uppträdande de lärt sig i rollen som läkare.

Jag kan redan här avslöja att de berättelser som analyseras i denna artikel innehåller liknande inslag av omförhandling av det sociala och kulturella kapital som tycktes vara gångbart på till exempel en arbetsplats. I likhet med de polska läkarna berättade våra intervjupersoner om hur de känt sig tvungna att finjustera sitt uppträdande efter de rådande normerna.

\section{Att förstå framgångsrika karriärer i samband med migration}

Pierre Bourdieus (t.ex. 1977, 1986, 1990) diskussion om symboliskt kapital är en utgångspunkt för den analys jag gör i denna studie. En central aspekt av Bourdieus teori är att symboliskt kapital formas av individers och gruppers mobilisering av resurser och tillgångar. I överförd mening kan man säga att symboliskt kapital är ett slags ammunition i konkurrensen om makt och inflytande mellan såväl individer som institutioner (Broady 1998: 20). I karriärsammanhang konkurrerar vi om tjänster och utmärkelser genom att mobilisera meriterande sociala resurser och utnyttja dem som ett slags kapital (jfr Lin 2000). Personliga attribut som personlighet och läggning är inte oviktiga, men symboliskt kapital ger en förstärkningseffekt till de personliga egenskaperna. Ålder, klasstillhörighet, etnicitet och könstillhörighet kan påverka individens förutsättningar att lösa in sitt symboliska kapital.

Processen med att få resurserna erkända som värdefulla meriter är särskilt viktig i min analys. Utbildningsmeriter och sociala referenser kan ge en fördel när vi söker en kvalificerad anställning, men inom ett annat socialt fält - till exempel ett yrkesområde där kraven på utbildning ser annorlunda ut och vår högt uppsatta referens är okänd - är värdet på samma kapital betydligt lägre (jfr Bourdieu 1986: 249). 
Saker och ting blir mer komplicerade i samband med migration. Genus och klass är avgörande för individens chanser att skaffa sig makt och inflytande, men det finns stora kontextuella skillnader som påverkar utfallet av detta maktspel (Anthias 2007). Migration spetsar till denna fråga om hur individer kan flytta fram sina positioner. Kriterierna för vad som är meriterande för en viss maktposition ser ofta annorlunda ut mellan länder och kulturer. Dessutom finns i allmänhet skillnader i hur en viss meritering ska bedömas. Individer som har erövrat sitt kapital i ett land kan ha svårt att få det erkänt $i$ ett annat land med ett annat utbildningssystem och med andra måttstockar och maktförhållanden. De kan inte luta sig mot det nätverk av referenspersoner som de har ackumulerat i hemlandet (Young 20I4). De måste i allmänhet mobilisera ett nytt kapital. Symboliskt kapital är inte resurser som kan packas in och ut ur en ryggsäck när det passar oss (Erel 20IO).

Det finns ett manöverutrymme för individer att påverka hur deras kapital omvandlas och omsätts. De sociala fälten kan skilja sig mycket åt, och särskilt individer som migrerar blir mer eller mindre tvingade att aktivt få sina kapital värderade. Migranter anlägger strategier för att hantera den situation och den ordning som de möter i det nya samhället. Det speglas i det de berättar om sin sociala bakgrund och sina erfarenheter på den nya arbetsmarknaden (Bourdieu \& Wacquant 1992).

\section{Framgångsrika karriärer som berättelser}

Den metodologiska grunden för denna studie finns inom den antropologiska och etnologiska forskning som utgår från narrativ i form av intervjuer, individuella utsagor med mera (jfr Denzin 1997; Riessman 2008) eller berättelser om sociala processer och förhållanden.

Genom att studera våra informanters individuella berättelser har jag fått syn på vilka strategier de använde för att mobilisera ett symboliskt kapital i ett nytt samhälle, och vilka handlingar och omständigheter de betraktar som avgörande för sina karriärframgångar. Berättelserna ger en insikt i migranternas villkor.

För den här studien intervjuades 32 personer som var födda i ett land i Mellanöstern (Iran, Irak och Turkiet). Samtliga kan, enligt de yviga 
kriterier som jag tidigare angav, betecknas som framgångsrika. I urvalet ingår att de har gjort sin huvudsakliga karriär inom ett av två sociala fält: affärsvärlden och högskolan. Eftersom intervjuerna till stor del speglar individernas erfarenheter inom sina karriärer öppnar detta material också för en diskussion om skillnader mellan dessa fält.

Urvalet består av 19 män och I3 kvinnor. 28 personer är födda i Iran, tre i Irak och en i Turkiet. Åtminstone sex personer är av kurdiskt ursprung och ytterligare någon tillhör, eller har släktingar från, någon annan minoritet i regionen. Alla namn på informanter i artikeln är fingerade.

De flesta av de intervjuade har eller har haft höga positioner inom sitt yrke. Hälften av dem ("akademikerna") är disputerade forskare med sin huvudsakliga karriär inom högskolan, och den andra hälften ("affärsmännen") var eller hade varit verksamma inom näringslivet som företagare eller chefer.

Intervjuerna hade en samtalsliknande form; frågorna var öppna och intervjupersonerna fick stort utrymme att svara på det sätt som passade dem. I samtliga intervjuer ställde vi inledningsvis några ledande frågor kring individernas personliga biografier (med början i ursprungslandet) och vi såg också till att deras berättelser omfattade deras erfarenheter av att komma till Sverige och etablera sig där. I en del fall handlade det också om deras liv i ett annat destinationsland. Detta gör att samtliga informanter gett oss sin version av de omständigheter och villkor som varit viktiga för att de skulle komma fram till den position de hade vid intervjutillfället.

Informanterna gjorde i de flesta fall själva anspråk på en medelklassbakgrund. Dessutom hade de synnerligen goda utbildningsmeriter. En självkritisk anmärkning till intervjuerna med akademikerna är att vi och de naturligtvis hade mycket gemensamt, och vi kände igen oss i mycket av det de berättade. Det finns en risk för att de gemensamma referenserna stod i vägen för ett helt fritt berättande, vi kunde till exempel ha gemensamma bekanta och intervjupersonerna ville kanske inte framhäva sina egna prestationer inom det sociala fält som vi delade.

Framgång i yrkeslivet i Sverige handlar mycket om utbildning, men det utesluter inte att goda kontakter har stor betydelse. I den här artikeln diskuterar jag detta faktum i relation till migranter från Mellanöstern 
och hur de berättar om sina framsteg. Många av informanterna framställde sina kulturella erfarenheter av en uppväxt i ett annat land som ganska odramatiska och välbekanta för det svenska samhället. Alla är svenska medborgare och de kan, vad jag förstår, flytta tillbaka till sina hemländer om de så önskar. De hade samtliga skaffat sig en karriär i det svenska samhället. Flera av dem hade bott i andra europeiska länder eller i Nordamerika sedan de lämnade sitt ursprungsland. Några av dem hade dessutom lämnat Sverige som ett led i sin karriär. Vid tiden för intervjuerna var tre av våra informanter bosatta i Spanien och en i USA.

\section{Informanternas bakgrund}

De flesta av våra informanter kom till Sverige under 1980-talet eller början av 1990-talet, några redan under 1970-talet. Samtliga av dem hade lämnat sitt födelseland i unga år - i tonåren eller i tidig vuxenålder - och lämnat sin familj i samband med flykten. Men några informanter hade kommit till Sverige som barn och tillsammans med sina föräldrar.

Deras personliga förhållanden speglade i stort sett de förhållanden som rådde i Mellanöstern vid tiden för deras migration. Politiska och sociala oroligheter var den främsta orsaken till att de migrerade. För många av informanterna var deras personliga historier knutna till religiösa och politiska omvälvningar och konflikter i området, framför allt den iranska revolutionen 1979, Iran-Irak-kriget under 1980-talet och det kurdiska upproret under ungefär samma tidsperiod. Även de som hade flyttat till Sverige före den iranska revolutionen hade ofta på ett eller annat sätt drabbats av omvälvningarna i regionen, medan några av informanterna uppgav att framtidsutsikterna drastiskt försämrades i samband med den iranska revolutionen men att de själva inte utsatts för förföljelse eller trakasserier.

I flera berättelser framställs migrationen som en stegvis flytt från land till land. Först till ett grannland, och några informanter hade dessutom bott i ett eller flera andra länder innan de kom till Sverige. Det handlade i dessa fall oftast om en flykt från diktatur och förföljelse. En annan vanlig orsak till att man flyttade till Sverige var studier. Att informanterna valde just Sverige berodde i en del fall på att de hade ett 
syskon, en kusin eller någon annan släkting som redan bodde där, men i andra fall framställdes flytten som en slumpmässig händelse. I många berättelser nämndes också släktingar som är bosatta i något europeiskt land eller i Nordamerika och som på olika sätt påverkat beslutet att lämna hemlandet.

Flyktingmigration har ofta påtagliga inslag av intellektuella, studenter och aktivister från medelklassen. Det märks främst bland de iranska migranterna i Sverige: deras utbildningsnivå ligger över riksgenomsnittet och även över infödda svenskars (SCB 20I7). Frågan om utbildning var central i våra intervjuer. De flesta av informanterna hade tillhört minst medelklassen (eller motsvarande) i Iran, Irak eller Turkiet.

Informanterna hade i de flesta fall vuxit upp under välbärgade förhållanden där utbildning ofta var en självklarhet. Men även om de redan hade påbörjat (eller till och med avslutat) en utbildning innan de kom till Sverige, så fick de efter ankomsten sätta sig på skolbänken igen. I allmänhet berodde det på att deras betyg och examen från hemlandet inte var värda något i det svenska samhället eller att sådan dokumentation var ofullständig eller saknades. Det ledde i en del fall till att de kompletterande sin utbildning, men de flesta valde i det läget att gå vidare med en ny utbildning som antogs ge dem bättre chanser i Sverige.

Helhetsintrycket från intervjuerna är att samtliga informanter var välkvalificerade för sina yrken. Med tanke på att de flesta hade en svensk utbildning i ryggen torde varken bristande språkkunskaper eller okända utbildningsmeriter ha hindrat dem från att konkurrera om välkvalificerade yrkespositioner. Men att vara invandrad i Sverige innebär att ställas inför utmaningar som infödda inte möter. Invandrade personer får i allmänhet sämre utdelning på sina studiemeriter än vad infödda får (Behtoui 2006; Behtoui \& Olsson 20I4; Katz \& Österberg 2013). Jämfört med infödda svenskar har migranter - även högutbildade - betydligt lägre lön i snitt och ett större arbetslöshetstal. 


\section{Familj och hemland i karriärbiografier}

I så gott som samtliga fall tycktes informanterna ha en positiv syn på sin uppväxt. De beskrev sina föräldrar som omhändertagande och uppoffrande. Uppenbarligen hade föräldrarna utgjort ett stöd i livet så länge familjen bodde i hemlandet. Föräldrarna var i de flesta fall utbildade åtminstone fadern - och några hade en universitetsutbildning. Bara en av de 32 intervjuade uppgav att föräldrarna saknade utbildning. De berättade också om ett samhälle där tilltron till utbildning varit stor. Att skaffa sig en utbildning var en nödvändighet för att göra karriär och få ett bra yrke.

I några av intervjuerna framgick att det var före den iranska revolutionen som föräldrarna haft sina goda år men att läget hade förändrats till det sämre efter 1980. Det var inte ovanligt att familjen hade en bakgrund som småföretagare inom handel eller service. I dessa berättelser hade informanterna i de flesta fall sin fars samhällsställning i åtanke och nämnde enbart i förbigående att modern tog hand om hemmet och barnen. Några av dem berättade emellertid om sin mor och hennes yrke, och i ett fall hade modern en hög samhällsposition.

En av informanterna, Kenan, berättade att hans familj var jordägare och ledare för en av de större kurdiska familjerna i området. Hans barndom präglades av familjens privilegierade ställning i det kurdiska samhället, men det var också en tid som präglades av upproret mot centralregeringen.

En av informanterna, Aida, framställde föräldrarnas uppoffring som en investering i familjens framtid:

Jag växte upp i en familj med en far som arbetade som tjänsteman inom sjukvården. Min mor var hemmafru men min pappa hade alltid ett ideal om att flickor måste utbilda sig, bli oberoende, ekonomiskt oberoende - och han var verkligen extrem på den punkten! Så man fick inte göra annat än att studera. ... Vi pluggade intensivt. Jag läste naturvetenskap i en riktigt fin skola, trots att vi egentligen inte hade råd till det. Men det var en investering som min far gjorde!

Detta stöd från föräldrarnas sida var ett privilegium, men medaljens baksida var de krav och förväntningar som följde med uppoffringarna. Flera av informanterna talade om att familjen väntade sig att studierna skulle 
ta dem långt i samhället, till yrken som läkare och jurist. Det var emellertid mycket hård konkurrens till dessa utbildningar och flera medgav att de inte hade kommit in. Ett exempel är Mina. Efter att ha avslutat sina gymnasiestudier i Teheran i början av 1970-talet var hon fast besluten att studera vidare på ett tekniskt universitet. Det var stenhård konkurrens om platserna, hon lyckades inte bli antagen och visste inte vad hon skulle företa sig. Minas bror hade emellertid flyttat utomlands redan tidigare och var bosatt i Sverige. Efter att ha fătt tips och råd av honom blev hon själv intresserad av att fortsätta sina studier utomlands. Men Mina var bara sjutton år och en sådan plan krävde föräldrarnas samtycke:

Både min mamma och min pappa var otroliga. Min pappa sa alltid till oss: "Ni kan bli vad ni vill bli." Det var hans budskap. Världens snällaste pappa och väldigt stödjande. Men det tog ett tag innan jag kunde övertala min far, för jag ... Vi stod varandra väldigt nära då. Men han förstod att jag hade bestämt mig. Han hade uppfostrat mig så att jag fick bestämma själv alltid. Så då gick han med på det. Men då sa han: "Okej, men då får du ta med dig din lillebror."

Situationen för informanterna med kurdiskt ursprung var förmodligen mer komplicerad. De var uppvuxna med ett minoritetsspråk och det fanns spänningar mellan kurder och majoritetsbefolkningen, åtminstone i Irak och Turkiet. Det hindrade dock inte att de talade på samma sätt om familjen och om nödvändigheten av att studera för att kunna göra en bra karriär.

Informanternas berättelser hade ett medelklassperspektiv. De poängterade att de var produkter av ett samhälle som värderade utbildning högt. Deras uppväxt hade urbana inslag och inbegrep samhällsföreteelser och miljöer som är välbekanta för en västerlänning. Även för de informanter som hade vuxit upp på landsbygden tycktes berättelserna placera dem i staden och i sin syn på utbildning och karriär skilde de sig inte nämnvärt från dem som vuxit upp i städer.

Samtidigt hade givetvis informanterna kommit i kontakt med andra slags värden och normer. Det är högst troligt att Mina, som ville utbilda sig vid ett tekniskt universitet till ett traditionellt manligt yrke, konfronterades med omgivningens fördomar. Kenan växte upp i en kurdisk familj med feodal anknytning men tycktes trots det ha haft ungefär samma erfarenheter som de informanter som växte upp i medelklassens 
Teheran. Hans uppväxt i en välbärgad familj i det turkiska Kurdistan innebar att han fick en bra skolgång och var välbekant med liknande moderna konsumtionssamhällen som Sverige.

Informanternas berättelser säger något om vilka typer av kulturella erfarenheter som är värdefulla i en karriär. Om vi ser närmare på vad berättelserna inte uttrycker ser vi att kanterna tycks ha slipats för att passa formen på det svenska samhället. Det är rimligt att tänka sig att de som växte upp på den turkiska eller iranska landsbygden på ett eller annat sätt präglades av de kulturella värden som rådde där, och jag hade på förhand förväntat mig att informanterna implicit eller explicit skulle säga att de hade nått framgång trots sin bakgrund. De traditionella sidorna av livet i hemlandet tycktes dock tonas ned eller glömmas bort. Jag menar att det kan förklaras av att berättelserna var färgade av den strategi som informanterna uppfattade som framkomlig och relevant. Informanterna berättade i huvudsak om sin uppväxt i ljuset av sina framgångar i det svenska samhället. De skapade mening åt sin berättelse genom att rama in den med det kapital och den habitus som kan ha haft betydelse för karriären. Det kan, som såväl Kelly (2013) som Konyali (2015) varit inne på, handla om att de presenterade sig på ett sätt som de uppfattade som okontroversiellt i det svenska samhället.

\section{Karriärvägar i ett nytt samhälle}

När vi kom in på informanternas yrkeskarriär i Sverige lämnade berättelsen de positiva och värdefulla erfarenheterna från uppväxten i hemlandet. Det är kanske vad man skulle kunna förvänta sig, men det visar ett brott i biografin som hade med migrationen att göra men också med vilka resurser som hade betydelse i det nya samhället.

Informanternas berättelser om livet i Sverige kändes i allmänhet ganska avdramatiserade. De handlade om exceptionella karriärer men framfördes i ödmjuka och vardagliga ordalag. Det fanns också vittnesmål om diskriminering och planer som gått i stöpet när arbetsgivare eller kunder hade "valt svenskt". Informanterna hade en del att berätta om sin utbildning, om personer som de mött i olika sammanhang, samt om problem de fått övervinna för att lära sig ett nytt språk och sätta sig in i hur samhäl- 
let fungerade. Många av informanterna var unga när de kom till Sverige och hade inte hunnit fullfölja sina studier eller kommit så långt i karriären innan de lämnade sitt land. Andra blev varse att deras studiemeriter från hemlandet var otillräckliga i Sverige. I stället för att genomgå långa kompletteringsutbildningar och krånglig byråkrati som kanske inte skulle leda någonstans började flera av informanterna på ny kula.

Berättelserna speglar migrantens - åtminstone nykomlingens - perspektiv på att göra karriär i ett nytt samhälle. I stället för att nämna den draghjälp de haft av sin familj eller av familjens vänner lyfte de nu fram till exempel en lärare eller en chef som hade fungerat som en omtänksam mentor eller rådgivare under informantens första tid i Sverige. Detta stöd hjälpte dem att ta sig in i yrket eller hade på något annat sätt möjliggjort en avgörande vändning. På denna punkt var skillnaderna mellan affärsmännen och akademikerna påtagliga. En framgång i karriären tar sig dock olika uttryck inom affärssektorn och den akademiska världen.

\section{Affärer på Ingemar Stenmarks vis}

Det finns inom affärsvärlden olika uppfattningar om vad framgång är. Men ett vedertaget kriterium torde för de flesta företagare och chefer vara att göra bra affärer, tjäna pengar och vinna makt och inflytande genom att äga företag och ingå i styrelser. Detta avsnitt handlar om informanternas framställning om vad som gjort det möjligt för dem att driva ett lönsamt företag eller nå en hög position. I bakgrunden till berättelserna finns ett samhälle som inte på något uppenbart sätt släpper fram nykomlingar.

En av de informanter i vårt material som lyckats exceptionellt bra med sitt företag var Sasan. Som många andra invandrade från Iran började han studera vid universitetet kort efter ankomsten till Sverige. Han gjorde lysande framsteg och på häpnadsväckande kort tid hade han doktorerat inom ett naturvetenskapligt ämne. Sasan hoppade emellertid av sin karriär som forskare. Den forskargrupp han ingick i hade splittrats och uppenbarligen hade han också andra intressen: redan före avhoppet hade han på sin fritid börjat bygga datorer hemma i köket. Efter att ha lämnat forskarbanan fick han öka produktionstakten och kunde så småningom få en liten vinst på sin verksamhet. Samtidigt fick marknaden 
för persondatorer ett kraftigt uppsving och beställningarna ökade. När Sasan kunde ägna mer tid åt sin verksamhet gick också affärerna strålande. Inte så många år senare var han redan företagsledare för en hel koncern av företag inom datorkonsultbranschen. När han skulle förklara varför det gått så bra sade han att det bland annat berodde på att han haft mycket tur. Att han fick uppleva it-vågen och gav sig in i affärsverksamhet under 1990-talets första hälft, i stället för att stanna inom akademin, verkar ha varit en avgörande orsak.

Sasan uttryckte en uppfattning som är betydligt vanligare bland de affärsmän vi intervjuade än bland akademikerna: turen har stått på deras sida och skänkt dem denna framgång. I en del fall tycks det som om informanterna har råkat befinna sig på rätt plats vid rätt tillfälle. De framställer det som att de har ridit på en våg eller burits fram av en serie omständigheter.

Även Khai kunde utnyttja 1990-talets it-våg till sin fördel. Det var en ren chansning, menade hon. Hon hade en bakgrund inom matematik men saknade idéer om vad hon skulle göra av den. I brist på annat hoppade hon på en kurs i datorprogrammering:

På arbetsmarknaden fanns det hur mycket jobb som helst! Alla skrek efter programmerare! Så med tanke på ... jag hade barn och min man var sjuk då ... Jag kände att "jag börjar jobba så fort som möjligt". Så jag började jobba och jag blev aldrig klar med utbildningen.

Våra informanter berättade om sina framgångar på ett lågmält sätt. Men det saknades inte antydningar om att de kom sig av något annat än att informanterna hade råkat snubbla in i något eller träffats av blixten. Hårt arbete och viss begåvning kan ha varit bidragande orsaker. Som en illustration av förhållandet mellan habitus och kapital i Bourdieus mening tycks de turliga omständigheterna ha varit det som fick de personliga egenskaperna att blomma upp.

Sasan hade inte bara haft turen på sin sida utan också varit sin egen lyckas smed. Att klara av utbildningen rekordsnabbt och etablera ett snabbväxande it-företag krävde naturligtvis hårt arbete. För att förklara hur han hade hamnat i denna våg av ekonomisk framgång och vad det innebar tog Sasan hjälp av ett citat av den svenske slalomstjärnan Ingemar Stenmark: 
Jag jobbar jättehårt! Och som Ingemar Stenmark någon gång lär ha sagt: ju mer han tränade desto mer tur fick han! Så jag tror det är samma sak även för oss. Ju mer vi jobbar, ju hårdare vi kämpar, desto mer tur får vi. Och det tror jag är sant, för att ju mer du jobbar och ju mer du är ute och kämpar, desto mer är du utsatt för att få tur och desto mer utsatt för att vinna något!

Shahron är ett annat exempel på när detta flyt i tillvaron infinner sig. Av hennes berättelse att döma etablerade hon sig som företagare i Sverige vid precis rätt tillfälle. Hon hade genomgått en universitetsutbildning i Iran och redan som nyexaminerad fått anställning vid socialdepartementet. Där avancerade hon ganska snabbt till en chefsposition med ansvar för ett område inom vården. Shahron säger att hon i grunden hade ett bra liv med många vänner och ett arbete som hon var nöjd med. Men Iran var i krig med Irak och de politiska förhållandena gjorde livet allt svårare. Shahron lämnade därför Iran i slutet av 1980-talet tillsammans med sin man och deras barn. Eftersom Shahrons bror var politisk flykting i Sverige kunde de få ett turistvisum för att besöka honom.

Till en början hade familjen inga konkreta planer på att bosätta sig i Sverige, säger Shahron. Det ena gav dock det andra och när Shahron och hennes familj hade bestämt sig för att de ville stanna fick de efter en kort väntan sina permanenta uppehållstillstånd.

Shahron fann sig snabbt tillrätta och trivdes med livet på en mindre sydsvensk ort. Sverige passade deras önskemål eftersom det var ett land med många möjligheter. För egen del började hon studera svenska och kompletterade sina tidigare universitetsstudier från Iran med en preparandutbildning på universitetet. Därefter bestämde hon sig för att studera till sjuksköterska. Under några år arbetade hon på olika sjukvårdsinrättningar i regionen och flyttade så småningom till en närliggande större stad där möjligheterna för framför allt barnen var mycket bättre.

I intervjun berättade Shahron om vilka uppoffringar som hade krävts för att gå så pass snabbt fram med utbildning och arbete:

Jag var ändå den kvinnan som hade blivit befriad och kunde döva samvetet hos några. De [arbetsgivare inom vårdsektorn] är väldigt "duktiga" och gav mig, en "förtryckt kvinna”, ett jobb. Det var på den nivån då. Och jag insåg det väldigt tidigt, jag måste bygga min egen plattform. Jättebra system, väldigt omhändertagande! Men på något sätt bromsande för din karriär. ... Det är inte bara jag, det är många, även svenskar, som måste bryta de här barriärerna. ... Men som 
jag sa i min TED [...]: vi kanske betalar ett högre pris för att vi var tvungna att bevisa att vi är duktigare. Jag menar: Fanns det något jobb, då var du tvungen att vara tio gånger duktigare än en svensk kollega för att få det. Prata mycket, mycket bättre svenska, även som många svenskar. Du har korrekt svenska, du använder inga svärord, du är korrekt i allt. Och det uppfostrade mig och tränade mig för den rollen som jag tog sedan, att det här är verkligheten, det här är möjligheten, det här är barriärerna.

Shahron gav en bild av att osäkerhet, frustration och hårt arbete dominerade i början av hennes karriär i Sverige. Det var slitsamt att hoppa runt på olika vårdinrättningar utan någon ordnad situation. Som "invandrarkvinna" mötte hon fördomar, och hon upplevde sjukvårdssystemet som trögt och stelbent. Shahrons planer på att starta ett eget företag tog form. Hon hade först försökt få en utveckling i sin karriär genom att under stora umbäranden komplettera med en master i en annan stad medan familjen bodde kvar i hemstaden. Inte heller detta förlöste hennes frustration. Under en tid jobbade hon i Norge, där lönen och arbetsförhållandena var betydligt bättre. Men Shahron ville, som hon uttryckte det, ha en sjukvård som gagnade patienterna och förkortade beslutsprocesserna.

Detta var i slutet av 1990-talet. I efterspelet till finanskrisen befann sig det svenska samhället i en omfattande omvandling av välfärdspolitiken. En konsekvens var att den offentliga sektorn delvis avreglerades och öppnade möjligheter för privata aktörer att erbjuda offentligt finansierad välfärd. Från sin tid vid socialdepartementet i Iran hade Shahron viss erfarenhet av hur privata vårdtjänster kunde utformas, och hon såg en möjlighet i den nya marknad som öppnade sig. Tiden var den rätta för att starta ett företag som erbjöd vårdtjänster, resonerade hon.

Shahron såg framför sig ett alternativ till den "kollektivisering" och den tröghet som hon ogillade. Hon skapade ett företag som skulle erbjuda individanpassade och flexibla tjänster. Uppenbarligen fann hon en nisch i det svenska samhället och dess tidsanda, och företaget blev snabbt mycket framgångsrikt. Efter att först ha etablerat en klinik i en medelstor stad i södra Sverige riktade hon blicken mot den lukrativa Stockholmsregionen. Hon vann ett antal upphandlingar även där, och omsättningen ökade betydligt. Verksamheten expanderade sedan inte 
bara storleksmässigt och till andra regioner utan gav sig också in på flera områden inom vård och hälsa. Det var grunden till en koncern av vårdrelaterade företag som så småningom växte till en omsättning på flera hundra miljoner kronor. Shahrons framgång är ingen slump. Hon har möjligtvis gripit tillfällen i flykten, men hennes berättelse handlar om att hon har slitit hårt för en sak som hon verkligen tror på.

De flesta av affärsmännen $i$ vårt material berättar om stora uppoffringar och hårt arbete. Exemplet Simon visar tydligt att framgång fordrar att man är villig att arbeta hårt och är öppen för nya möjligheter. Vi intervjuade Simon i en bullrig restaurang i närheten av hans företag i utkanten av Stockholm. Han berättade att han hade läst ekonomi på universitetet i Iran och redan som ung arbetat sig upp till att bli avdelningschef i ett företag inom detaljhandeln. När han kom till Sverige, innan han fyllt 30 år, var det som att börja om på nytt. Han studerade målmedvetet och försörjde sig på tillfälliga jobb.

Stegvis byggde Simon upp ett familjeföretag inom detaljhandeln, och vid tiden för intervjun hade det en årlig omsättning på omkring 700 miljoner kronor. Vad var hemligheten bakom detta?

Det är samma tankemönster som jag har fortfarande. Så långt som möjligt ... att tjäna mina egna pengar. ... Jag började arbeta som säljare när jag var sju år gammal. Jag har jobbat hela tiden när ... på mellanstadiet jobbade jag på eftermiddagarna, under högstadiet på eftermiddagarna. Jag jobbade när jag läste på gymnasiet och till och med när jag läste på universitetet jobbade jag nästan heltid och studerade nästan heltid. Sedan när jag gifte mig - det var samma sak! Jag måste ha mina egna pengar!

Simon reflekterade över sitt sätt att arbeta och jämförde med andra affärsmän på samma nivå som han själv. Det var fråga om en annan stil, en skillnad i företagskultur, menade han:

På grund av hur vi [inom företaget] tänker, hur vi resonerar, hur vi reagerar, ja då är vi annorlunda. Men det beror inte på ... [nationalitet, ursprung] Vi är mest doers, vi är mest pragmatiker, vi är mest ... flexibla. Vi har chefer som springer på lagret och jobbar själva. Det är det som skillnaden, inte på grund av att jag är iranier eller vad det kan bero på. Det är hur vi tänker, hur vi resonerar. Jag har sett samma typ av bolag som vi är i Tyskland, i Frankrike, i Sverige, i Norge ... 
Simon ville peka på en skillnad som inte hade med etnicitet eller nationalitet att göra, utan snarare rörde idealet om "entreprenörsanda" (Appadurai 20ı6; Barth 1967). Där kompletteras devisen "hårt arbete lönar sig" med rådet om att vara pragmatisk.

Simons berättelse om allt arbete han hade investerat i sitt företagsbygge var ganska gripande. En framgångsrik karriär skapas dock inte bara med en ofantlig massa timmar och kämparanda, utan under karriären måste man fatta smarta beslut för att lyckas, menade Simon. Företagare måste också ständigt vara alerta och lära sig nya saker.

Det lyser igenom i Simons och Shahrons berättelser att en del att hemligheten bakom framgångsrikt företagande är att ingjuta förtroende i såväl kunder som samarbetspartner, investerare och andra som kan ha intresse av företaget. Detta märks också i finanskonsulten Hasses (en pseudonym som han själv valde) berättelse. Innan hans rörelse expanderade och tog en ny riktning i Spanien ägde Hasse ett gatukök i Stockholm. Trots att det var en liten rörelse var det viktigt att ha kunskap om de produkter som gatuköket serverade och deras ingredienser:

Om du kommer att bemöta folk som frågar dig med "ja, hmm ...", då blir de osäkra. Men om du säger det rakt ut: "Det där innehåller ... det där innehåller något ... som nötter eller något annat ...", då säger de "bra” och då vet de att du kan! Då kommer de tillbaka. Även om de vill prova något annat, då frågar de och de vet att du kan. Jag tror att det är en av orsakerna till att Sverige är så framgångsrikt i världen. Alltså, jämför den här befolkningen och det här lilla landet med resten av världen! Det är för att de är så duktiga, de är kunniga.

Sammanfattningsvis målar berättelserna från affärsmännen upp en bild av entreprenören i en klassisk skepnad, som når framgång med en perfekt kombination av handlingskraft och tur kryddat med ett strategiskt och pragmatiskt sinnelag. Att "ha tur" i livet kan uppfattas som något bortom individens kontroll - särskilt när det rör sig om skeden på ett makroplan, som konjunkturer och marknadshändelser. Berättelserna ger samtidigt en indikation på att turen går att tygla.

Ett försök att ringa in ordet tur med en mer analytisk språkdräkt kan vara att se turen som ett tillstånd där individuell handlingskraft står i ett slags synkront förhållande till makroskeden (Erel \& Ryan 2019: 248). Individen lyckas (ofta utan att vara helt medveten om det) iscensätta en 
handling i precis rätt ögonblick för att få det resultat som hon hoppats på. För att dra nytta av vad som sker på ett större samhälleligt plan och förstå hur marknaden utvecklar sig krävs förmodligen också att man har spelplanen klar för sig. Det går att spekulera i om informanterna under sin uppväxt och sin utbildning har lärt sig att göra "situationsanalyser", men det strategiska tänkandet förefaller vara en viktig grundpelare i en framgångsrik karriär. I det ingår förmodligen en beredvillighet att ta risker. Uppenbart krävs också en stark vilja som inte är främmande för uppoffringar och hårt arbete. Men jämfört med infödda svenskar kanske migranter, som Shahron uttryckte det, "betalar ett högre pris för att vi var tvungna att bevisa att vi är duktigare”. I Sverige är deras meriter från ursprungslandet inte gångbara, och att de till exempel hade en stark familj och kontakter som öppnade dörrar i Iran saknar betydelse. Deras symboliska kapital har devalverats. En del av deras framgångsrecept tycks ha varit att kunna acceptera detta faktum och strategiskt mobilisera nya resurser. Att vara migrant och konkurrera med infödda på en marknad är definitivt att kämpa underifrån (Leivestad \& Olsson 2020).

\section{Akademisk frustration}

Forskare som är angelägna om att göra karriär inom högskolan måste i allmänhet se till att få forskningsmedel och meritera sig genom publicering. Det är inte i första hand en hög lön som är bytet, utan tjänster, positioner och forskningsanslag. När det gäller den konkreta karriärvägen handlade akademikernas berättelser till stor del om att de så snart som möjligt skaffade sig de meriter som krävdes för att få en tjänst och för att få sin forskning bekräftad.

Akademikerna var inte benägna att framhäva det hårda arbete de lagt ner för att lyckas med sin forskarutbildning eller för att slå sig fram i den hårda konkurrensen om anslag och tjänster. Som Behtoui och Leivestad (20I8) påpekar är det en konst i sig att författa en ansökan till en forskarutbildning. Studenter lär sig sällan att skriva sådana och andra ansökningar under sin utbildning. I början av sin forskarkarriär blir dessutom de flesta varse att de måste lära sig att skriva avancerade forskningsplaner och söka olika slags bidrag. All denna kunskap är i huvudsak tillgänglig genom informella kanaler. Forskare och lärare som redan är inne i hög- 
skolans system kan hjälpa nykomlingar med hur man skriver ett cv och formulerar sig i en forskningsplan.

Inom högskolan är det sällan avgörande att ha väldigt goda kunskaper i det svenska språket - engelska går ofta bra. Däremot är det viktigt att behärska konsten att uttrycka sig tydligt, att svänga sig med de rätta referenserna och i övrigt lägga sig till med en stil som "går hem" (Behtoui \& Leivestad 20I8). Det finns kanske inget färdigt manuskript för hur man skriver en perfekt projektansökan, men det går att träna upp förmågan genom att skriva många ansökningar, åta sig uppgifter där det ingår att bedöma andras ansökningar och i övrigt socialiseras in i det akademiska livet (jfr Trower \& Chait 2002). Det finns med andra ord en rad informella resurser som är viktiga att se och ta fram för att mobilisera det symboliska kapital som ger framgång inom högskolan (jfr Behtoui 20I7).

Akademikerna vittnade om att de under sina första år hade saknat insikt i hur det gick till att meritera sig och vad som krävdes för att etablera sig som en framgångsrik forskare. Frustration var ett påtagligt inslag i deras berättelser. De talade sällan om individuell läggning och skicklighet. I stället tillmätte de forskningen och forskningsområdet stor betydelse. När erkännandet till slut kom tog karriären ett språng i rätt riktning.

Till skillnad från affärsmännen prisade inte akademikerna i någon större utsträckning sin "tur", snarare hänvisade de till ett slags "turordning” och till det spel som omgärdar tjänstetillsättning och anslagsbeviljande.

Det finns många exempel i akademikernas berättelser på situationer och händelser då maktspel och åtminstone indirekt diskriminering satte krokben för nästa steg i karriären. Känslan av att ha ett sämre utgångsläge än sina i huvudsak svenskfödda kolleger var utbredd. Akademikerna upplevde att deras bakgrund gjorde det svårare att få uppdrag och vikariat som var meriterande för framtida tjänster. En stor del av intervjuerna ägnades åt de intriger och ränker i tillsättningar och utnämningar som de upplevt genom åren. Flera av informanterna hade själva på ett eller annat sätt blivit drabbade av fördomar, diskriminering och maktspel, men framför allt talade de om kolleger som hade blivit det. 
En forskare inom ett medicinskt ämne berättade om en tjänstetillsättning där hen hade blivit rankad som nummer två, och även den sökande som rankades som nummer ett hade invandrat till Sverige. Enligt informanten hade institutionen haft synpunkter på detta resultat och ingen av de två fick tjänsten. I stället drogs tjänsten tillbaka "utan någon som helst förklaring”. Detta var ett av de undantag då en akademiker uttryckte besvikelse över att personligen ha drabbats av diskriminering.

Den främsta källan till akademikernas frustration var maktspelet och den orättvisa turordningen till tjänster och forskningsmedel. Institutionernas hackordning gjorde sig påmind när uppdrag skulle fördelas och när det skulle antas doktorander. Starka seniora forskare kunde pressa på för att deras forskningsinriktning skulle gynnas och att det skulle antas doktorander som passade detta. Den som lyckades bemästra detta sociala spel och erövra en plats långt fram i den kö som ledde till prestigefyllda uppdrag eller forskningsanslag kunde bli framgångsrik. Vilka resurser krävdes för att klara det?

Det ligger nära till hands att se framgång i ljuset av det spelsinne, i Bourdieus (1990) mening, som krävs för att bli skicklig på att navigera $\mathrm{i}$ det akademiska sociala landskapet. Det kan säkert finnas ett slags talang - eller habitus - som gör att vissa individer är mer skickliga i att navigera i sociala sammanhang. Men det hindrar inte att det som i affärsmännens berättelser framställdes som tur också spelade in i akademikernas karriärer. Det fanns flera exempel på situationer då tillfälligheter spelat in, till exempel då informanten haft turen att träffa en etablerad forskare eller blivit tilldelad en handledare som sedan fătt stor betydelse för den fortsatta karriären.

I en tidigare artikel (Olsson m.fl. 2018) konstaterade vi att det inom högskolan finns en rad olika sätt att göra karriär på. Det går givetvis att avancera genom att meritera sig den traditionella vägen genom tjänster och befordran men det är inte alltid som en strikt meritokratisk bedömning avgör hur detta slutar (jfr Schoug 2004). Dessutom finns såväl parallella som komplementära spår som stärker individens chanser att avancera. Det kan handla om att få ett uppdrag, bli tillförordnad på en meriterande position eller erövra ett prestigefullt forskningsbidrag. Hur man kan lyckas på dessa punkter finns sällan genomskinligt beskrivet i 
tydliga kriterier. Men chanserna för att lyckas ökar förmodligen om den som tar sig an utmaningen får stöd från sin institution och från kolleger och andra i sin omgivning. De individer som har erfarenheter och insikter i detta komplexa belöningssystem får ofta en viktig roll för att vägleda andra. Vikten av att ha tillgång till sådana personer märks i våra informanters berättelser. I flera fall nämndes en handledare eller en mer erfaren kollega som fungerat som mentor eller brobyggare. Det kunde röra sig om att ge konkreta synpunkter på en forskningsplan eller ställa upp som referens för ett uppdrag. I de flesta fall hade denna nyckelperson i informantens liv ett svenskt namn.

Vilken miljö en nybliven doktorand hamnar i kan ha stora konsekvenser för den fortsatta karriären. Intervjuerna ger en rad exempel på betydelsen av att tillhöra rätt gruppering vid lärosätet och institutionen. Forskning bedrivs ofta som ett lagarbete. Rekryteringen till ett framgångsrikt team inom institutionen sker genom kontakter och matchning av intressen. Flera informanter nämnde kafferummet som en betydelsefull informell arena på arbetsplatsen där kolleger utbyter information och bygger nätverk, kläcker forskningsidéer och knyter lojalitetsband.

En professor i humaniora berättade om sin tid som doktorand. Hon och några andra "utländska doktorander" hade sitt "lilla gäng, hade jättekul med varandra, arbetade hårt, [...] men vi hade inte ens rum i det här huset där andra satt”. Placeringen hade både symbolisk och praktisk betydelse. Den rumsliga isoleringen av de "utländska doktoranderna" gjorde att de blev en grupp för sig och delvis isolerades från sina kolleger. Dessutom hade de av språkliga skäl svårt att göra sin röst hörd i det institutionella sammanhanget. Informanten och hennes doktorandkolleger saknade ett kollektivt sammanhang där de kunde få insikter i och kunskap om de mer komplexa sidorna av forskarkarriären. De fick kort sagt inte samma möjligheter som övriga att ta sig fram inom högskolan.

Det förekom också att informanterna hade haft turen att tilldelas en handledare som blivit en bundsförvant och ledsagare på institutionen och varit ett stöd i den fortsatta karriären. En forskare i ett samhällsvetenskapligt ämne berättade: 
Jag hade tur, för min handledare var en ung vänsterorienterad fin människa som uppmuntrade mig hela vägen från kandidat- till masteruppsats och för att komma in på doktorandutbildningen. [...] Men det var otur samtidigt, för hon själv var ganska marginell på sin institution och inte en del av den mäktiga gruppen inom institutionen som var kvantitativa forskare. De ogillade min handledare och hennes doktorander [...] och efter min disputation blev handledaren också sjukskriven för att hon själv inte mådde bra i miljön.

Ett exempel på betydelsen av mentorskap finns i Anas berättelse. Ana fick under slutskedet av sina studier på grundnivå av en ren tillfällighet träffa en av de etablerade forskarna vid institutionen. De började samtala om ett gemensamt forskningsintresse och forskaren uppmuntrade Ana att berätta mer ingående om vad hon ville forska om. Det första mötet slutade med att Ana fick i uppgift att skriftligt formulera en forskningsplan för fortsatta diskussioner. Det var helt oväntat, berättade Ana, och hon visste inte ens vad som skulle ingå i en forskningsplan. Men uppmaningen gjorde att Ana fick syn på ett viktigt moment i kompetensen som forskare. Genom att lära sig hur en forskningsplan skrevs tog Ana ett steg in i forskarvärlden. Det ledde till fortsatta kontakter med denna forskare och så småningom en doktorandplats vid institutionen.

Även för Tariq var ett möte med en etablerad forskare avgörande. Tariq hade tagit en annorlunda väg till den politiska världsscen som han med tiden hamnade på. Han föddes i Iran men flyttade som barn till Sverige efter att familjen tvingats fly under den iranska revolutionen. Berättelsen målade upp bilden av en ung man som ville se världen, samtidigt som han var djupt engagerad i frågor som rörde det iranska samhället.

Tariqs uppväxt i en svensk förortsmiljö är otypisk för personer som gjort liknande karriärer. Men studierna var viktiga och han gick ut gymnasiet med mycket bra betyg. Under en resa i USA blev han av en tillfällighet bekant med en politiker som tog honom under sina vingar. Senare studerade han ett samhällsvetenskapligt ämne i Sverige och kunde med denne politikers hjälp få en praktikplats i Washington. Så småningom bestämde sig Tariq att fortsätta sina studier i USA med hjälp av ett Fulbrightstipendium. Av en tillfällighet blev han presenterad för en världsberömd professor. Genom professorns försorg antogs han som doktorand vid ett 
stort amerikanskt universitet och fick ägna sig åt det forskningsämne som intresserade honom mest. Tariqs avhandling var strategiskt intressant $\mathrm{i}$ den amerikanska politiska kontexten. De två mötena, med politikern och den berömda professorn, visade sig vara nyckelhändelser som möjliggjorde avgörande språng i karriären.

Det sociala spel, de viktiga personer och de mentorskap som informanterna talar om är informella sociala resurser som, vid sidan av formella meriter, kan ge skjuts åt forskarkarriären. Berättelserna speglar den komplexitet som omgärdar karriärer inom högskolevärlden. Visserligen är meritokratin en ledstjärna vid tjänstetillsättningar, men sociala kontakter har stor betydelse när det gäller att skaffa sig meritering. Det finns ett subtilt kommunikationssystem inom högskolan som bland annat kommer till uttryck i "dold rekrytering" (Nielsen 2015). Meritokratin kan kringgås genom att annonsen för en tjänst skräddarsys för en viss person och dras in om andra kandidater riskerar att rankas högst. Med hjälp av handplockade sakkunniga kan institutionen utöva inflytande över tillsättningen.

Genom att komma in i de rätta kretsarna kan man få tillgång till den "dolda läroplan” (Broady 198I; Margolis 200I) som omgärdar forskarnas yrkesutövande. När de ser tillbaka på sin karriär inom högskolan framhåller informanterna situationer där det gäller att spela sina kort rätt och där rutin och erfarenhet ger tydligt utslag. Till det hör att ha insikt om vilka forskarkolleger och team som har inflytande, men också möjligheten att få kollegers stöd i samband med färdigställande av publikationer och ansökningar. Det är viktigt för den som är i början av sin karriär att hitta rätt forskningsämne och att vara strategisk när det gäller att få uppmärksamhet och forskningsbidrag. Den forskningsmiljö man ingår i kan vara behjälplig med att hitta de sammanhang där det finns forskningsanslag och resurser. Att tillhöra ett lag som är känt för sin vetenskapliga produktion är en viktig fördel när man söker tjänster och uppdrag. Att ha kontakter och bli rekommenderad spelar dessutom en stor roll för om man utses till att vara redaktör för en vetenskaplig tidskrift, granska en avhandling eller sitta i en betygsnämnd.

Akademikerna i vårt material fäster stor vikt vid det sociala spel som de anser styr utvecklingen av deras karriär. I det avseendet är det egent- 
ligen inget som skiljer dem från kolleger födda i Sverige. Det krävs ett spelsinne, som inbegriper att vara strategisk och hitta allianser och samarbeten med nyckelpersoner som kan vara stödjande och öppna dörrar. Att ge sig in i spelet innebär att man riskerar att konkurrera med kolleger och hamna i konflikt med dem.

Informanterna i denna studie har gett sig in i detta sociala spel som "främlingar" (Behtoui 20I7) och måste på nytt såväl mobilisera sociala kontakter som skaffa sig kunskaper om hur fältet ser ut. Diskriminering och fördomar lurar bakom hörnet, men intressant nog tonade informanterna ned dessa förhållanden. Det har att göra med villkoren och reglerna för det sociala spel som de gett sig in i. Den som vill vinna makt och inflytande har inte råd att bjuda rivaler på gratis ammunition. För att inte språksvårigheter eller kulturellt annorlundaskap ska bli ett argument mot dem måste de migranter som vill göra karriär försöka smälta in och acceptera spelets regler.

\section{Avslutande diskussion}

I den här artikeln har jag riktat strålkastaren mot migranter med ursprung i Mellanöstern och deras berättelser om sina framgångsrika karriärer i det svenska samhället.

Ur mitt Bourdieuinspirerade perspektiv visar berättelserna hur individerna har mobiliserat resurser och format gångbara kapital för att lyckas i karriären. Att symboliskt kapital värderas och erkänns i relation till sociala fält får en särskild innebörd i samband med migration: i det nya landet värderas ens formella meriter och ens professionella kontaktnät lägre. Det symboliska kapitalet ifrågasätts och måste mobiliseras på nytt.

Jag har under analysen gjort fyra observationer. Den första handlar om den medelklassposition som uttrycks i berättelserna. I allmänhet har föräldrarnas stöd och uppoffringar varit mycket viktiga för informanterna. Det var naturligt och förväntat att de skulle slå in på en bana där en avancerad utbildning skulle ta dem till ansedda och välbetalda yrken. Dessa ambitioner är vanliga bland de mer välbeställda skikten i Mellanöstern, liksom i det västerländska samhället. Jag menar inte att 
berättelserna försöker dölja de kulturella skillnader som finns, men de tyder på strategier där typiskt västerländska medelklassvärden är en tillgång. Även i de fall då informanterna vuxit upp under förhållanden som markant skiljer sig från dem som råder i det svenska samhället syns en rörelse mot kulturell likhet i intervjuerna. Min tolkning är att individer som vill ta sig fram i det svenska samhället har mer att vinna på att betona likheter än annorlundaskap. Informanterna presenterade sig som personer som hade goda förutsättningar att smälta in i det svenska samhället och undvek troligtvis att framstå som personer med en mer exotisk erfarenhet.

Den andra observationen handlar om svårigheten att överföra symboliskt kapital mellan olika länder och sociala fält (Erel \& Ryan 2019). Informanternas sociala bakgrund, familj och andra sociala relationer är resurser som skulle kunna mobiliseras i ett gångbart kulturellt och socialt kapital. Så länge informanternas berättelser rörde sig i hemlandet var familjen och de närmsta vännerna levande inslag i biografin. Men när de talade om karriären i det svenska samhället var dessa potentiella resurser som bortblåsta. Med ett undantag (en företagare inom kultursektorn i Sverige) satte de parenteser kring det sociala kapital som de hade mobiliserat i hemlandet. Berättelserna innehåller i stället en hel del referenser till personer - exempelvis mentorer och lärare - som varit viktiga för etableringen i det svenska samhället eller, i en del fall, i det samhälle som de flyttat vidare till. Akademikernas berättelser var särskilt starkt präglade av de sociala relationernas och det sociala spelets betydelse för karriäravancemang. Eftersom deras medhavda sociala resurser i allmänhet inte värderades som socialt kapital var det avgörande för dem att skaffa sig nya sociala kontakter och sammanhang.

Även det kulturella kapitalet (utbildningsmeriter, examina) genomgick en nedskrivning i och med migrationen. De flesta av informanterna var visserligen inte färdiga med sina studier när de kom till Sverige, men här valde de en bana som passade det svenska samhället. Att de kände sig tvingade att utbilda sig på nytt eller åtminstone komplettera sina tidigare meriter kan i vissa fall ha berott på att de inte hade fått all dokumentation med sig och därför inte tyckte det var någon större idé att fortsätta studierna i den riktningen. Men troligtvis hade de flesta en utbildning i 
bagaget som inte bedömdes leda någon vart i det svenska systemet. Det illustrerar Bourdieus teori att symboliskt kapital är sammanflätat med sociala fält och de maktstrukturer som är etablerade där.

Min tredje observation handlar om skillnaderna mellan akademin och affärsvärlden. Alla informanter hade liknande bakgrund och samhällsposition. Skillnaderna mellan affärsmännen och akademikerna framträdde när de talade om sin karriär i Sverige. Affärsmännen hänvisade till sin "tur" i livet, där jag kunde urskilja två komponenter: Dels det synkrona förhållande som tycks råda mellan informanternas biografi och vissa historiska skeenden och makrohändelser, till exempel it-boomen under 1990-talet. De som strategiskt utnyttjade möjligheterna i en uppskruvad efterfrågan på vissa produkter och tjänster kunde göra en framgångsrik karriär. Dels entreprenörsanda, att informanterna var engagerade, pragmatiska och villiga att arbeta hårt för det de ville uppnå. I affärsmännens berättelser märks att de etablerade sig på den svenska marknaden utifrån en position som slog underifrån. En lyckad karriär för akademiker går vanligtvis genom publikationer, stora forskningsanslag och prestigefyllda tjänster. I konkurrensen med kollegerna om anslag och tjänster slog även akademikerna bland mina informanter underifrån eller till och med som främlingar, som Behtoui (20I7) hävdar. Akademikernas framgång byggde i hög grad på att de förmådde mobilisera sociala resurser som kunde omvandlas till socialt kapital. I deras berättelser framträdde hur de därför försökte bemästra det sociala spelet inom sitt professionella fält. En annan skillnad mellan affärsmännen och akademikerna är att de förra i högre grad tycktes betona sin habitus (personlighet och egenskaper), medan de senare betonade socialt kapital (fruktbara forskningsmiljöer och allianser).

Den färde och sista observationen handlar om etnicitet och den erfarenhet som kan kallas "migrantskap". Särskilt akademikernas berättelser präglades av erfarenheter av att möta fördomsfullhet och lida brist på sociala kontakter. De flesta tycktes emellertid personligen inte ha blivit diskriminerade i någon vidare utsträckning. Framgångsberättelserna tonade ned sådana störningar på vägen framåt. I stället gav de intrycket av en linjär biografi där det var ganska odramatiskt att flytta från ett land till ett annat och där en pragmatisk inställning kunde lösa problemen med 
att accepteras och smälta in. Återigen valde informanterna att betona det som de uppfattade som likt svenska värden och den kultur som kännetecknar det svenska samhället snarare än att lyfta fram de skillnader som fanns eller skulle kunna finnas. Berättelserna var tydligt formade av de professionella sociala fält och den klass där informanterna rörde sig (Van Hear 20I4), medan deras etnicitet och migrantskap tonades ned. Såväl etnicitet som migrantskap kom dock in bakvägen i berättelserna. Intervjuernas utgångspunkt var att vi ville samla in berättelser från personer med ursprung i Mellanöstern som hade gjort en framgångsrik karriär i Sverige. I berättelserna speglas inte bara den personliga biografin utan också dess villkor. De som lyckades inom affärsvärlden eller akademin hade, av berättelserna att döma, utrustat sig med en pragmatisk inställning till kulturella och etniska skillnader. Vinnarna i karriären var, som så ofta annars, de som lyckades smälta in och anpassa sig.

\section{Referenser}

Anthias, Flora, 2007, "Ethnic ties. Social capital and the question of mobilisability", The Sociological Review, vol. 55, nr 4, s. 788-805 DoI: https://doi.org/IO.IIII\%2Fj.I467-954X.2007.00752.x

Appadurai, Arjun, 2016, Banking on words. The failure of language in the age of derivative finance, University of Chicago Press, Chicago

Barth, Fredrik, 1967, "On the study of social change", American Anthropologist, vol. 69, nr 6, s. 66I-669 DoI: https://doi.org/I0.1525/aa.1967.69.6.02a0oo2o

Behtoui, Alireza, 2006, Unequal opportunities. The impact of social capital and recruitment methods on immigrants and their children in the Swedish labour market. Linköpings universitet, Institutionen för samhälls- och välfärdsstudier, Linköping

Behtoui, Alireza, 20I7, "'Främlingen' bland svensk 'Homo academicus", Sociologisk forskning, vol. 54, $\mathrm{nr}$ I-2, s. 9I-IO9 URL: https://sociologiskforskning.se/sf/article/view/18207 (2 december 2020)

Behtoui, Alireza, 20I8, "Etniska hierarkier och (icke-)representation. Partikandidater med migrationsbakgrund vid svenska valet 20I4", Sociologisk forskning, vol. 55, $\mathrm{nr}$ 2-3, s. 317-339 URL: https://sociologiskforskning.se/sf/article/view/I8195 (2 december 2020)

Behtoui, Alireza \& Leivestad, Hege Høyer, 20I8, "The 'stranger' among Swedish 'homo academicus'", Higher Education, vol. 77, nr 2, s. 213-228 DOI: https://doi.org/I0.1007/sio734-0I8-0266-x 
Behtoui, Alireza \& Olsson, Erik, 20I4, "The performance of early age migrants in education and the labour market. A comparison of Bosnia Herzegovinians, Chileans and Somalis in Sweden", Journal of Ethnic and Migration Studies, vol. 40, nr 5, s. 778-795 DoI: https://doi.org/10.1080/1369183X.2013.836958

Bennich-Björkman, Li \& Likic-Brboric, Branka, 20ı8, "Svensk integrationspolitik och integration i Sverige. Hur har det gått för 1990-talets högutbildade flyktingar från Bosnien och Hercegovina?", Högutbildade migranter i Sverige, red. Maja Povrzanović Frykman \& Magnus Öhlander, Arkiv förlag, Lund, s. 2II-227

Bourdieu, Pierre, 1977, Outline of a theory of practice, Cambridge University Press, Cambridge

Bourdieu, Pierre, 1986, "The forms of capital", Handbook of theory and research for the sociology of education, red. John G Richardson, Greenwood press, New York, s. 24I259

Bourdieu, Pierre, 1990, The logic of practice, Stanford University Press, Stanford

Bourdieu, Pierre \& Wacquant, Loïc, 1992, An invitation to reflexive sociology, University of Chicago Press, Chicago

Broady, Donald, I981, Den dolda läroplanen, Symposion, Järfälla

Broady, Donald, 1998, Kapitalbegreppet som utbildningssociologiskt verktyg, Uppsala universitet, Uppsala

Carlsson, Magnus \& Rooth, Dan-Olof, 2007, "Evidence of ethnic discrimination in the Swedish labor market using experimental data", Labour Economics, vol. I4, nr 4, s. 716-729

DOI: https://doi.org/I0.IOI6/j.labeco.2007.05.00I

Denzin, Norman K, 1997, Interpretive ethnography. Ethnographic practices for the 2Ist century, Sage, Thousand Oaks

Ekberg, Jan, 1992, Vad hände sedan? En studie av utrikes födda på arbetsmarknaden, Högskolan i Växjö, Växjö

Ekberg, Jan, 20I6, ”Det finns framgångsrika flyktingar på arbetsmarknaden”, Ekonomisk Debatt, vol. 44, nr 5, s. 6-II

URL: https:/www.nationalekonomi.se/sites/default/files/2016/o9/44-5-je.pdf (2 december 2020)

Erel, Umut, 20I0, "Migrating cultural capital. Bourdieu in migration studies", Sociology, vol. 44 , $\mathrm{nr} 4$, s. $642-660$

DOI: https://doi.org/10.1177/0038038510369363

Erel, Umut \& Ryan, Louise, 2019, "Migrant capitals. Proposing a multi-level spatiotemporal analytical framework", Sociology, vol. 53, nr 2, s. 246-263

DoI: https://doi.org/10.1177/0038038518785298

Frykman, Maja Povrzanović \& Öhlander, Magnus, red., 2018, Högutbildade migranter $i$ Sverige, Arkiv förlag, Lund

Frykman, Maja Povrzanović \& Mozetič, Katarina, 2020, ”The importance of friends. Social life challenges for foreign physicians in Southern Sweden", Community, Work \& Family, vol. 23, nr 4, s. 385-400 DoI: https://doi.org/IO.IO80/13668803.2019.1599323 
Graham, Mark \& Khosravi, Shahram, 1997, "Home is where you make it. Repatriation and diaspora culture among Iranians in Sweden", Journal of Refugee Studies, vol. Io, nr 2, s. II5-I33

DOI: https://doi.org/IO.I093/jrs/IO.2.115

Hosseini-Kaladjahi, Hassan, 1997, Iranians in Sweden. Economic, cultural and social integration, Almqvist \& Wiksell International, Stockholm

Irastorza, Nahikari \& Bevelander, Pieter, 2017, The labour-market participation of highly skilled immigrants in Sweden. An overview, Malmö University, Malmö

Irastorza, Nahikari \& Bevelander, Pieter, 20I8, "Högutbildade immigranters representation på svensk arbetsmarknad", Högutbildade migranter $i$ Sverige, red. Maja Povrzanović Frykman \& Magnus Öhlander, Arkiv förlag, Lund, s. 49-70

Katz, Katarina \& Österberg, Torun, 2013, "Wages of childhood immigrants in Sweden - education, returns to education and overeducation", Working Paper Series, nr 8, IFAU, Uppsala.

Kelly, Melissa, 2013, Onward migration. The transnational trajectories of Iranians leaving Sweden, Department of Social and Economic Geography, Uppsala University, Uppsala

Khosravi, Shahram, 1999, "Displacement and entrepreneurship. Iranian small businesses in Stockholm", Journal of Ethnic and Migration Studies, vol. 25, nr 3, s. 493-508 Dor: https://doi.org/Io.I080/1369183X.1999.9976697

Klinthäll, Martin; Mitchell, Craig; Schölin, Tobias; Slavnić, Zoran \& Urban, Susanne, 2016, Invandring och företagande, Delegationen för migrationsstudier, Stockholm

Konyali, Ali, 20I4, "Turning disadvantage into advantage. Achievement narratives of descendants of migrants from Turkey in the corporate business sector", New Diversities, vol. I6, $\mathrm{nr}$ I, s. IO7-I2I

URL: https://newdiversities.mmg.mpg.de/?page_id=I793 (2 december 2020)

Konyali, Ali, 20I7, "International opportunities on the way up. Alternative career paths of descendants of migrants from Turkey in the field of professional business services", Ethnic and Racial Studies, vol. 40, nr 2, s. 264-282 DoI: https://doi.org/I0.I080/OI4I9870.2017.1245430

Leivestad, Hege Høyer \& Olsson, Erik, 2020, ”A 20 dollar note. 'Success stories' of Swedish business actors with Iranian origin", Social Identities, vol. 26, nr 2, s. 219-232 DOI: https://doi.org/Io.I080/I3504630.2019.1711049

Lin, Nan, 2000, "Inequality in social capital", Contemporary Sociology, vol. 29, nr 6, s. $785-795$

DOI: https://doi.org/I0.2307/2654086

Margolis, Eric, 200I, The hidden curriculum in higher education, Routledge, New York

McNeil-Walsh, Colleen, 2008, "Migrant nurses and the experience of skill. South African nurses in the UK health care sector", The International Migration of Health Workers, red. John Connell, Routledge, London

Mählck, Paula, 20I3, "Academic women with migrant background in the global knowledge economy. Bodies, hierarchies and resistance", Women's Studies International Forum, vol. 36, s. 65-74

DoI: https://doi.org/IO.IOI6/j.wsif.20I2.09.007 
Najib, Ali B, I999, "Invandrarföretagande. Livsverk eller påtvingad lösning?”, Etnicitetens gränser och mångfald, red. Erik Olsson, Carlsson Bokförlag, Stockholm, s. I23I55

Nielsen, Mathias W, 20I5, "Limits to meritocracy? Gender in academic recruitment and promotion processes", Science and Public Policy, vol. 43, nr 3, s. 386-399 DOI: https://doi.org/IO.IO93/scipol/scvo52

Nowicka, Magdalena, 2012, Deskilling in migration in transnational perspective. The case of recent Polish migration to the UK, Comcad, Bielefeld

Olsson, Erik, 2020, "Re-made in Sweden. Success stories in a Swedish migration context", Nordic Journal of Migration Research, kommande

Olsson, Erik; Behtoui, Alireza \& Leivestad, Hege Høyer, 20I8, ”Karriär på spel. Socialt kapital och karriär för disputerade migranter i den svenska högskolan”, i Högutbildade migranter i Sverige, red. Maja Povrzanović Frykman \& Magnus Öhlander, Arkiv förlag, Lund, s. I95-2II

Riessman, Catherine Kohler, 2008, Narrative methods for the human sciences, Sage, Thousand Oaks

Sandelind, Clara \& Ådahl, Martin, red., 2010, Lyckad invandring. Tio svenska forskare om hur man når framgångar, Fores, Stockholm

SCB, 2017, Utrikes föddas utbildningsbakgrund 20I7, Statistiska centralbyrån, Örebro

Schoug, Fredrik, 2004, På trappans första steg. Doktoranders och nydisputerade forskares erfarenheter av akademin, Studentlitteratur, Lund

Slavnic, Zoran, 20Io, "Invandrares småföretagande i Sverige - en kritisk skildring av forskningsfältets utveckling”, Möjligheternas marknad. En antologi om företagare med utländsk bakgrund, red. Åsa-Karin Engstrand, Tillväxtverket, Stockholm, s. I3I-162

Trower, Cathy A \& Chait, Richard P, 2002, "Faculty diversity. Too little for too long", Harvard Magazine, vol. I04, nr 4, s. 33-37 och 98

URL: https://www.umkc.edu/provost/chairs/meetings/Meeting\%2odocs/Fac_ Diversity_Harvard_Mag.pdf (2 december 2020)

Van Hear, Nicholas, 20I4, "Reconsidering migration and class", International Migration Review, vol. 48, $\mathrm{nr}$ I, s. IOO-I2I

DoI: https://doi.org/IO.IIII/imre.I2I39

Wolanik Boström, Katarzyna, 2005, Berättade liv, berättat Polen. En etnologisk studie av hur högutbildade polacker gestaltar identitet och samhälle, Umeå universitet, Umeå

Wolanik Boström, Katarzyna \& Öhlander, Magnus, 20II, "Polska läkare i Sverige. Om läkarroll, status och kulturella processer", Socialmedicinsk tidskrift, vol. 88, $\mathrm{nr} 3$, s. $273-28 \mathrm{I}$

URL: https://socialmedicinsktidskrift.se/index.php/smt/article/view/789 (2 december 2020)

Wolanik Boström, Katarzyna \& Öhlander, Magnus, 2012, A troubled elite? Stories about migration and establishing professionalism as a Polish doctor in Sweden, Comcad, Bielefeld

Wolanik Boström, Katarzyna \& Öhlander, Magnus, 2015, "Renegotiating symbolic capital, status, and knowledge. Polish physicians in Sweden", Rethinking ethnography in 
ARKIV | NR I2

Central Europe, red. Hana Cervinkova, Michal Buchowski \& Zdeněk Uherek, Palgrave Macmillan, London, s. 4I-58

Young, Yvette, 20I4, "Social context and social capital. Governance, inequality, and the individual experience", International Journal of Sociology, vol. 44, $\mathrm{nr}$ 2, s. 37-62 DoI: https://doi.org/I0.2753/IJSoo20-7659440202

Öhlander, Magnus; Wolanik Boström, Katarzyna \& Pettersson, Helena, 2020, "Knowledge transfer work. A case of internationally mobile medical professionals", Nordic Journal of Migration Research, vol. Io, $\mathrm{nr}$ 2, s. 36-49

DoI: https://doi.org/IO.33134/njmr.I36 


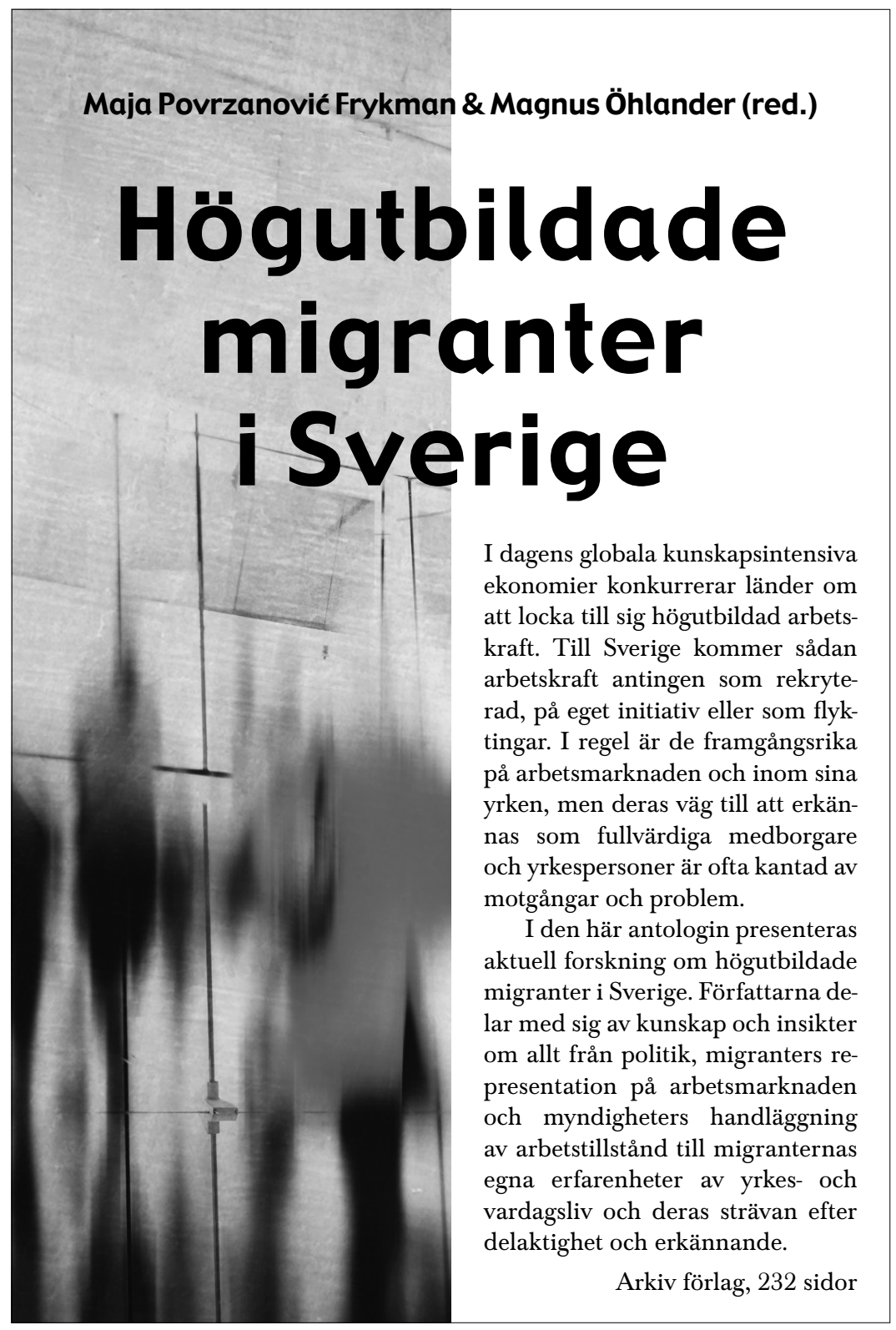

\section{»Läs mer om boken på www.arkiv.nu«}


Hur blir man medborgare och vad betyder det att vara medborgare? Medborgarskapet kan vara den efterlängtade slutdestinationen för en lång och mödosam flykt, men det kan också vara startpunkten för en svårdefinierbar integrationsprocess. Antologin VÄGAR TILL MEDBORGARSKAP handlar om

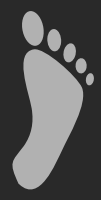

medborgarskapets villkor och förutsättningar i Sverige och världen idag.

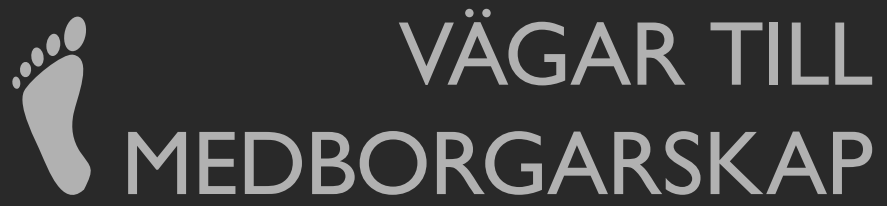

Pieter Bevelander, i Christian Fernández \& Anders Hellström (red)

Arkiv förlag, danskt band, 173 sidor »Läs mer om boken på www.arkiv.nu巛 